\title{
Soft Tissue Sarcoma of the Head and Neck pM1 TNM Finding v8
}

National Cancer Institute

\section{Source}

National Cancer Institute. Soft Tissue Sarcoma of the Head and Neck pM1 TNM Finding v8. NCI Thesaurus. Code C136662.

Soft tissue sarcoma of the head and neck with distant metastasis. (from AJCC 8th Ed.) 